\title{
The Effect of Board Roles on Firm Environmental Governance
}

\author{
Azar Shahgholian \\ Teesside University Business School \\ Email: A.shahgholian@tees.ac.uk
}

\begin{abstract}
In recent years much attention has been paid to firms' environmental profile. Implementing and improving firm's environmental profile are twofold. First, launching the environmental governance is a foundation for firm's environmental profile. Second, the characteristics of board of directors directly affect the decisions made by board on all firm's performance. Drawing on the resourcedependence theory and agency theory, board characteristics represent board resource-provision role and board monitoring role.
\end{abstract}

This paper aims to understand how the board monitoring and board resource-provision roles influence firm's environmental governance for 267 US firms from 2010 to 2012 . The findings confirm that effective boards increase their monitoring of management when there are more independent directors on the board, higher CEO-chairman duality, higher share ownership for insiders and the CEO and finally lower share ownership for outsider-directors. Boards with strong social network connections, larger board size and lower board tenure are classified as resource-rich boards. The results also confirm that resource-rich boards with effective monitoring roles tend to have a board, or a committee appointed by the board that is responsible for environmental initiatives, paying incentives for the management of climate change issues, publishing information in annual reports, voluntary communications and other regulatory filings.

Keywords: Board social network, Environmental governance, Board characteristics, Resourcedependence theory, Agency theory, Data mining.

\section{Introduction}

Most activities of firms are associated with multiple impacts on the environment. Although the impacts vary across sectors and subsectors, firms pay more attention to environmental issues that matter to investors, shareholders, customers and the greater society. During recent decades, firms have increased their attempts to measure and report their environmental profiles. This is evidenced 
by increasing firm participation in environmental voluntary initiatives, publishing their environmental activities, adopting the ISO 14001 as the international benchmark of environmental management systems, and self-regulation as a set of internal goals and initiatives.

The literature on companies' environmental profile is vast, offering a rich list of explanations for the relationship between environmental and financial profile of companies. Although a large number of empirical studies have provided evidence of positive relationship (e.g. (Hourneaux et al., 2014), (Iatridis 2013)); others have shown a negative relationship (e.g. (Chen et al. 2014), (Sariannidis et al. 2013)) or even have supported insignificant results (e.g. (Böhringer et al. 2012), (Post et al. 2011)). A key insight from the literature is that studies only focused on the outcomes of environmental profile for example $\mathrm{CO}_{2}$ emission, $\mathrm{KLD}$ environmental concerns or KLD environmental strengths and usually ignore the fact that environmental profile is multidimensional.

In addition, given the fact that the board of directors is responsible for protecting shareholders' interests and making decisions about major firm issues, implementing and developing the environmental profile of the firm is an agenda for the board of directors. It is a mission of the board to develop the firms' environmental profile by providing knowledge and other resources (Pfeffer and Salancik 1978; de Villiers et al. 2011) and ensuring that management endeavours to address the environmental agenda (Russo and Harrison 2005; Berrone and Gomez-Mejia 2009).

Hillman and Dalziel (2003) propose two roles for the board, namely: (i) monitoring management (based on the agency theory); and (ii) facilitating access to the resources and information (based on the resource-dependence theory). Accordingly, the board plays both roles in relation to developing an environmental profile. A key insight is that the characteristics of board and the roles they are playing in decision making are not fully considered by previous literature.

The aim of this paper is to further our understanding of those aspects of board of directors that refer to distinct but interrelated features that are important in considering, developing and maintaining a company's environmental performance. Therefoe, in this study, we use a set of board characteristics to represent the monitoring role of the board, which are board independence, CEO-chairman duality and director ownerships. In respect to the board's resource-provision role, we use two sets of board characteristics, namely, human capital (static) and social capital (relational) characteristics (Hillman and Dalziel 2003). The former refers to a set of characteristics for each individual board and includes board size and board tenure. The latter is the social network between firms, which refers to the position of the firm in relation to other firms and how this position in the network helps the board to facilitate access to resources and information. We then relate the two board roles to firms' 
environmental governance. We refer to environmental governance as a set of mechanisms and processes aimed at changes in environmental-related knowledge, decision-making and behaviours (Lemos and Agrawal 2006). When firms put environmental governance into practice, this is a sign of concern for the environmental profile of the firm. The implementation of environmental governance could be translated into: (i) assigning an individual or committee responsible for environmental initiatives, practices and progress; (ii) the presence of environmental incentives; and (iii) publishing the firm's climate change reports.

Our study offers four key contributions. First, it expands on board literature and follows (Hillman and Dalziel, 2003) framework to integrate both roles of the board of directors, namely, the monitoring function (based on agency theory) and providing resources (based on resource-dependence theory). The main reason is that these two roles of boards do not work in isolation and are often interrelated. This study is inspired by the work of (de Villiers et al. 2011). However, in this research we devote resource dependent role to human capitals (board size and board's tenure) and social capitals (social network).

Second, this paper contributes to the current literature on analysing the relationship between board social networks and firm environmental performance (Ortiz-de-Mandojana et al. 2012)(Diaz et al. 2013)(Ortiz-de-Mandojana and Aragon-Correa 2013)(Walls and Hoffman 2013)(Shahgholian et al. 2014)(Shahgholian et al. 2014).

Third, to the best of our knowledge, this study is the first to focus on environmental governance, while other studies mainly focused on the outcome of environmental activities such as $\mathrm{CO}_{2}$ emission, KLD environmental concerns or KLD environmental Strengths.

Forth, while most existing research works use multiple regression analysis, our study take advantage of state-of-the-art data mining technique to generate better predictive models than currently reported ones in the literature. In addition, utilising data mining technique is in line with the respond to a call from the literature to investigate "when" it is possible to improve environmental profile (Lankoski 2008) by highlighting the patterns between board characteristics and environmental governance.

The paper is organised as follows. Section 2 reviews the related literature and hypotheses. Section 3 describes the data sample and variables. Section 4 presents the analysis and interpretation of results, and Section 5 concludes the paper, describing potential areas for further research. 


\section{Background, Theory and Hypotheses}

In general, the board decision-making process is extremely complex and it is widely recognised that the characteristics of the board of directors have a direct impact on the decisions made by the board. Despite the number of studies conducted on boards of directors, there is still a quest for a deeper understanding of what drives board task performance (Pugliese et al. 2014). Recent developments in the field of firm's environmental profiles have led to an examination of the role of the board of directors in relation to firms' environmental performance (de Villiers et al. 2011; J. Walls et al. 2012). Many studies investigating the relationship between firm profile and environmental profile examine some of the board characteristics as firm profile. Because the focus of this study is only on board characteristics, we consider those studies that focus only on board characteristics in relation to firms' environmental profile. For example, three studies examine the CEO salary and compensation package in relation to environmental performance (Cordeiro and Sarkis 2008; Berrone and Gomez-Mejia 2009; J. L. Walls et al. 2012). There are four other studies examining a subset of directors' characteristics such as diversity, board independence, board size, board compensation, CEO-duality, insider/outsider directors, directors' average age and education (Prado-Lorenzo and Garcia-Sanchez 2010; Post et al. 2011; Post et al. 2014; Zou et al. 2014). All these studies provide some insights into the relationship between the characteristics of the board of directors and the firm's environmental profile. All of them suffer from analysing a narrow set of board characteristics. de Villiers et al. (2011) examine a more complete set of board characteristics, investigating the relationship between strong environmental performance and board characteristics that capture boards' monitoring and resource-provision abilities in respect to strong environmental performance and the related strategic opportunities. They define the environmental profile for each firm, which indicates whether a firm displays any of five environmental strengths reported in the KLD database. They analyse the sample of US publicly traded firms indexed in S\&P with data coverage on the KLD database for the 2003 and 2004 fiscal years. Their findings confirm that environmental strengths are positively and significantly related to director independence, and negatively and significantly related to directors appointed after the CEO. However, environmental strengths are insignificantly related to CEO-chair duality. Moreover, the results indicate an insignificant relationship between environmental strengths and CEO-director ownership, insiderdirector ownership or outsider-director ownership. The findings do not provide strong support for the association between multiple directorships and board tenure in relation to environmental strengths. On the other hand, environmental strengths have a positive association with board size, an active CEO and law experts. 
Research examining the impact of social network profile on environmental profile has received attention since 2012 and is therefore still at a developmental stage. The first study examining the impacts of director interlocks on firms' adoption of proactive environmental strategies was conducted in 2012 by (Ortiz-de-Mandojana et al. 2012). A sample of 90 US electric firms were classified as investor-owned firms in 2005. In this research, director interlocks are measured as the number of interlocking ties with other firms and define four types of supplier with director interlocks, namely, green equipment suppliers, firms providing a knowledge-intensive business service, financial institutions and fossil fuel suppliers. The reported analysis confirms that interlocks with green equipment suppliers have a positive impact on proactive environmental strategies. Three other types of interlock show negative relationships with proactive environmental strategies. Similarly, (Ortiz-de-Mandojana and Aragon-Correa 2013) analysed a sample of 93 US electric firms in 2005.They define director interlocks as the number of interlocking ties with other firms.Their findings confrim that firms with a higher number of interlocking director ties have a positive relationship with environmental performance, measured as a percentage of global warming potential divided by annual net generation. In addition, the firm's diversity interlock ties have a positive relationship with environmental performance. Walls and Hoffman (2013) examine the association between the social networks of the board of directors and positive environmental deviance. The research analyses 294 US firms from 2000 to 2008 and interlocking directorship is used to define the social network between firms. On this basis, they calculate degree centrality and eigenvector centrality. The findings indicate that more central firms, measured by either degree or eigenvector centrality in the network, are less likely to deviate positively from normal environmental practices in the institutional field. In 2013, Diaz et al. (2013) examined the role of social networks on environmental performance, analysing 310 S\&P1500 firms in the year 2008. Their definition of social network is that two firms are considered socially connected if they share at least one director or if one or more of their directors sit in a third firm in which another S\&P1500 firm director also sits. The findings show that firms that are socially connected have better environmental performance, as well as financial performance, measured by return on equity (ROE). In addition, socially connected firms pay incentives related to climate change, publishing information related to climate change and including information on their annual reports, and there is a responsible individual or team for climate change issues. Shahgholian et al. (2014) examined how the social network between firms (as one of the board characteristics) could impact the environmental performance of 202 S\&P1500 firms in the year 2011. In this work the "Current Employment (CE) Network of S\&P companies" is defined as follows: two SP firms are linked through a director if two firms share the same director. This is the traditional interlocking directorship network. Moreover, if directors from two firms sit on the board 
of a third firm, this will also form the CE of SP firms. The findings confirm that those firms with better social connections pay higher compensation and environmental incentives; they have a higher number of independent directors, publish annual reports and are willing to have voluntary communications. In addition, they have committees responsible for climate change.

\subsection{Environmental Governance}

In this study, we use three variables to describe environmental governance, namely, environmental responsibility team, paying environmental incentives and publishing environmental reports.

\subsubsection{Environmental Responsibility Individual/Team}

The purpose of an environmental committee is systematically to plan, implement and review sustainability policies and activities (Liao et al. 2014). Consequently, an existing environmental committee could help to prevent the agency problem. The environmental committee is likely to evaluate the advantages and disadvantages of environmental initiatives and provide more transparent and consistent environmental information. This could help the board of directors to prioritise environmental plans. When the board is directly responsible for environmental issues or there is a committee appointed by the board, it is more likely that the board will guarantee the development of an environmental profile by monitoring management. In addition, an environmental committee may enhance the awareness of employees about the environmental aspects of their jobs and responsibilities to reduce negative impacts. Such committees have the authority to set up monetary and non-financial rewards to encourage employees to take action in environmental activities (Liao et al. 2014).

\subsubsection{Environmental Incentives}

The role of paying financial incentives to motivate employees to take particular actions is evidenced by previous research (Conyon 2006). Paying environmental incentives could help to promote their sustainable management. Introducing an environmental incentive scheme can help to bring shareholders' interests and employers' behaviour closer together and minimise the agency problem. Firms may have several incentives to voluntarily improving environmental performance (Khanna and Anton 2002). In addition, firms may have an incentive to show themselves as being environmentally responsible (Rodrigue et al. 2013). Depending on the board's knowledge of employees' behaviour, it can design an appropriate reward scheme, either for all the employees or for a specific group such as a sustainability team or senior managers.

\subsubsection{Environmental Reporting}

As part of firms' environmental governance, they have a set of key performance indicators (KPIs) to evaluate the success of environmental activities. Therefore, firms attempt to collect, measure, 
manage and evaluate against KPIs and then report their environmental information. This process provides more transparency and comparability in their environmental profile (Matisoff et al. 2013). When the board has access to more reliable and up-to-date environmental information, it has more opportunities to monitor management in relation to developing an environmental profile. Firms usually publish their environmental reports through annual reports, voluntary reports or other regulatory fillings (Carbon Disclosure Project 2014), with the aim of providing insights into the main impacts on both the firm profile and the environment.

\subsection{Board Characteristics}

\subsubsection{Agency Theory and the Monitoring Function}

Management can pursue its own interests at the expense of shareholders' interests. One way to check such managerial activities and consequently improve firm performance is to employ monitoring and incentive-alignment mechanisms (Hillman and Dalziel 2003). The antecedent of the monitoring function is board incentives in order to motivate the board to protect shareholder interests (Hillman and Dalziel 2003). When board members are independent from the firm, they are more active in their monitoring responsibility (de Villiers et al. 2011). In addition, the evidence from agency theory shows that share ownership (equity compensation) is another motivation for board members to monitor management activities and decisions.

In recent years, environmental performance has been one of the major concerns of firms. However, the direct use of agency theory in the environmental profile of firms is scarce. Environmental performance requires significant investment, which might have uncertain outcomes and generally does not have immediate returns. Management are not interested in this sort of investment, which does not have short-term financial benefits to help increase their reputation and financial incentives. Therefore, it is important for boards to monitor and focus on decisions related to environmental performance. In this study, we consider board independence, CEO-chairman duality and share ownership as board characteristics with monitoring functions in relation to firm environmental profile.

Board independence. It is confirmed that because outside directors are independent from management, they are willing to monitor management more carefully and protect shareholder interests (Duchin et al. 2010)(lenciu et al. 2012)(J. Walls et al. 2012). Previous studies have investigated the role of independent directors on firm performance (Armstrong et al. 2014)(Wang 2014)(Cuadrado-Ballesteros et al. 2015). In relation to environmental performance, de Villiers et al. (2011) argue that a board with a higher concentration of independent directors is more likely to 
have direct knowledge and expertise of monitoring environmental performance and pursuing the available environmental opportunities. However, Walls et al. (2012) show that a larger number of independent directors generally undermines environmental performance.

CEO-chairman duality. When the CEO also holds the position of chairman of the board, the combination of the two roles provides significant power for the CEO. The main argument against CEO-chairman duality is based on agency theory, which predicts that CEOs, as agents of shareholders, do not always act in the best interests of shareholders. Supporting this conflict-ofinterest argument, previous studies have found that the combination of the CEO and chairman positions undermines the checks and balances in the top management of the firm (Romano and Guerrini 2012), and the board has less power to remove poorly performing managers (Goyal and Park 2002). A CEO who is also chairman of the board has more power to pursue a self-interested agenda and postpone other initiatives such as environmental investment with a long payback period.

Share ownership (insider-director ownership, outsider-director ownership, CEO-director ownership). Employee-share ownership refers to employees owning a proportion of their firms' shares (PoulainRehm and Lepers 2013). The primary goal of share ownership is to align everyone's interests on firm performance. Therefore, directors with greater share ownership are likely to focus on firm performance, because their decisions impact their own wealth. In support of this, prior research shows that a board with significant share ownership monitors CEO performance and is more likely to link CEO pay to firm performance (Bahaghat and Black 1999). More relevant to our study, Westphal (1999) and de Villiers et al. (2011) confirm that director ownership improves boards' monitoring of strategic decision-making. Therefore, directors with high share ownership are likely to support environmental initiatives. de Villiers et al. (2011, p.1644) state that "in the current climate of heightened environmental awareness, it is plausible that higher ownership could motivate directors to pursue green product and process innovations with potential to enhance shareholder value in the long run". In this study, we follow (Shivdasani 1993) and (de Villiers et al. 2011) and analyse the CEO-director ownership, insider-director ownership and outsider-director ownership separately. Insider-directors usually have large ownership; outsider-directors have small share ownership; and CEO ownership is also examined separately from the remaining insider-directors to consider the possible impacts of CEO ownership in relation to environmental performance.

Monitoring hypothesis: Firms are more likely to have better environmental governance as the monitoring role of their board increases. 


\subsubsection{Resource-Dependence Theory and the Provision of Resource Function}

A second board role is the provision of resources adopted by scholars in the resource-dependence theory. Resource-dependence theory is premised on the notion that all organisations critically depend on other organisations for the provision of vital resources (Drees and Heugens 2013). The primary concern of resource-dependence theory is board capital, which consists of both human capital and relational capital (or social capital)(Hillman and Dalziel 2003). The former refers to directors' experience, expertise and reputation, while the latter is the network of ties to other firms and external contingencies (Hillman and Dalziel 2003). Therefore, a larger board can bring more experience and knowledge to the board and offer better advice (Dalton et al. 1999). Board interlocks are likely to enhance coordination with important resource providers, primarily by providing an exchange channel of tacit or sensitive information and greater social cohesion between the key decision-makers representing the interlocked organisations (Mizruchi 1996)(Drees and Heugens 2013).

In terms of firms' environmental performance, there are significant differences between directors' experiences. Resource-rich directors are more likely to have knowledge of environmental issues and other firms' environmental agendas, which could help the board to plan environmental development. The contribution of at least one member into environmental practices could have a significant impact on the firm's environmental initiatives. This study considers board size, board tenure and board social networks as board characteristics related to the director's ability to facilitate access to the additional information and resources required for environmental performance.

Board size. Early research using resource-dependence theory focuses on board size as an indicator of the board's ability to provide resources to the firm (Hillman et al. 2009). A larger board offers more experience and knowledge and, consequently, better advice during the decision-making process (lenciu et al. 2012)(J. Walls et al. 2012). Therefore, larger boards are likely to have some directors with a certain level of environmental knowledge or directors that can provide access to the relevant resources and knowledge. Directors with such expertise can influence the board in relation to the opportunities and challenges of an environmental agenda. In addition, (de Villiers et al. 2011) support the positive impact of a large board on better environmental performance.

Board tenure. Longer director tenure means a long-term commitment to the firm. Directors with longer tenure are the source of knowledge about a firm's past performance and resources. Therefore, they can help the board with developing knowledge based on the firm's resources and performance in the past. However, along with this significant aspect of board tenure, there are also some negative aspects. Some studies suggest that long tenure is associated with less flexibility 
regarding change (Musteen et al. 2006). In addition, (Golden and Zajac 2001, p.1090) confirm that extended tenure of board members is associated with greater rigidity, and can result in entrenchment behind existing practices and procedures, with directors distancing themselves from new ideas. In such situations, a board with longer tenure may not be sufficiently flexible to establish an environmental agenda. Directors with shorter tenure have served on the boards of other firms more recently and therefore it is more likely to have more information related to the environmental initiatives of those firms.

Social networks. Social networks may facilitate value creation through the combination and exchange of resources (Tsai and Ghoshal 1998). Social networks enable the diffusion of knowledge, guide the allocation of resources and build consensus around best practice (Scott 2014). Social network analysis is the quantitative method used to build the social network profile of the board, which describes the position and behavioural characteristics of the board in relation to other firms in the network. The position of firms in the network is measured using social network centrality metrics, which are degree, betweenness, closeness and eigenvector (Shahgholian et al. 2015). The more centrally the firm is located, the more access it has to information and resources in the network (Granovetter 1985)(Walls and Hoffman 2013). The most recent empirical studies have linked director social networking profile to almost every important aspect of management and financial behaviour of firms, including shareholder value (Fogel et al. 2014), corporate finance policy decisions (Fracassi 2015), firm value (Fracassi and Tate 2012)(Larcker et al. 2013), CEO compensation (Hwang and Kim 2009)(Horton et al. 2012), director appointment (Qi 2011) and mergers and acquisitions (Fracassi and Tate 2012).

In the context of environmental initiatives, when the board is centrally positioned in the network, it can gain access to more information about environmental initiatives directly and find out more about other firms' environmental activities and developments. To the best of our knowledge, the research examining the impact of the social network profile on environmental profile has received attention since 2012 and is therefore still at a developmental stage (Ortiz-de-Mandojana et al. 2012)(Diaz et al. 2013)(Ortiz-de-Mandojana and Aragon-Correa 2013)(Walls and Hoffman 2013)(Shahgholianet al. 2014)(Shahgholianet al. 2014). Despite the differences in defining social networks and using a variety of social network metrics, as well as various environmental profile measurements, they all confirm the positive impacts of board social networking on the firm's environmental profile.

Resource provision hypothesis: Firms are more likely to have better environmental governance as the resource provision role of their board increases. 


\section{Research Method}

\subsection{Sample Selection}

Our initial sample was based on 4,233 firm-year observations listed as S\&P1500 firms, based on BoardEx (BoardEx 2016) data from 2009 to 2011. We used mainly BoardEx data to build social networks at firm level. In the next step, we merged social network data with environmental governance data derived from the Carbon Disclosure Project (CDP) (Carbon Disclosure Project 2013). Therefore, our sample reduced to 832 firm-year observations. The main reason for this is that it is mainly S\&P500 firms that report their environmental data to the CDP. Finally, we eliminated 60 firms without board governance data on the RiskMetrics. The final database consisted of an unbalanced panel data set of 267 firms from 2010 to 2012. We lagged board characteristics data by one year to allow for changes in environmental governance to take place based on the board characteristics in the previous year. Each record contains metrics related to the board's social network, a number of board characteristics and environmental governance subject areas. The sample was restricted to the S\&P1500 firms. The distribution of countries reveals that 99.05 per cent of the examined firms were from the US. The data covers 10 different industries classified by Global Industry Classification Standard (GICS) code; the largest representatives are financial (15.37\% of firms), information technology $(14.01 \%)$, consumer discretionary $(12.24 \%)$ and industry $(12.24 \%)$, health care $(10.75 \%)$, utilities (10.34\%), consumer staples (10.07\%), materials (8.03\%) and energy (5.44\%) industries.

\subsection{Research Design}

Figure 1 presents the variables and steps followed in this research. As it is discussed before, we consider two roles for board of directors. In order to define each role, a set of variables is employed. We employed data-mining techniques to model the impact of board characteristics on environmental governance. The methodology used in this analysis is a progressive clustering analysis approach. First, the K-Means (Alonso \& Shuster, 2002) algorithm was applied using only social network attributes as inputs to identify two initial clusters of firms, called socially connected and socially independent. Next, we applied the K-Means algorithm to the identified clusters in the previous step and a set of variables representing the board's resource-dependence characteristics. Two clusters are identified as follow: board with poor resource provision role and board with high resource provision role. In addition, firms were profiled by the set of board-monitoring characteristics and two specific clusters are identified which are board with high monitoring role and board with lower monitoring role. At this point, there were two sets of clusters for board monitoring and board resource-provision roles. In the final stage, the firm's environmental governance profile 
was formed by applying the K-Means algorithm to a set of environmental governance attributes and the board-monitoring and board resource-provision profiles of firms. Some additional analysis is shown on the relationships between the type of incentives and the individual or group entitled for that type of incentive.

\subsection{Variable Measurement}

A brief description of the variables used in this study is presented in this section.

Environmental Governance data. Environmental problems are often extremely complex and this is widely recognised as a multidimensional problem. While previous research focused mainly on environmental performance, including $\mathrm{CO}_{2}$ emissions (Fujii et al. 2013)(Pintea et al. 2014)(Misani and Pogutz 2015), GHG emissions (Hatakeda et al. 2012), environmental disclosure (Cong and Freedman 2011) and environmental management (Busch and Hoffmann 2011)(Uhlaner et al. 2012)(Tao and Zhang 2014), the focus of this study is on firms' environmental governance. 


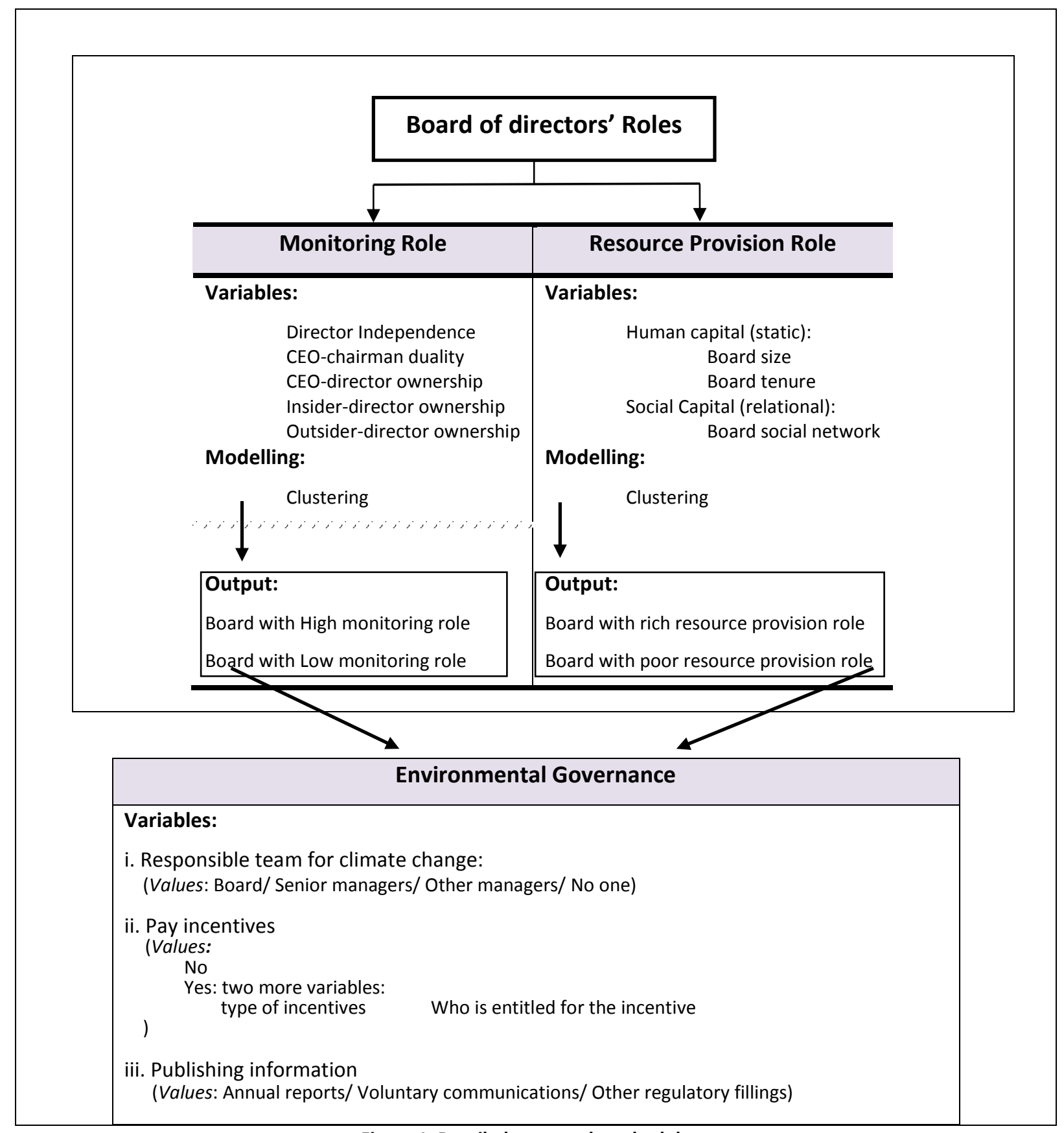

Figure 1. Detailed steps and methodology

The environmental governance data was obtained from the Carbon Disclosure Project (CDP). The CDP's data is used extensively in academic research (Kim and Lyon 2011)(Diaz et al. 2013)(Lee et al. 2013)(Shahgholianet al. 2014). The Carbon Disclosure Project (CDP) is a UK-based, not-for-profitorganisation, formed in 2000 as a United Nations initiative. Its mission is to gather and disseminate climate change information in an effort to create a unified response to global warming (Carbon Disclosure Project 2013). One category of questions is related to firm environmental governance and 
includes cc_responsibility, pay_incentives, intentives_type, incentives_entitiled, publishing_cc_reports.

cc_responsibility was constructed based on the firms' responses to this CDP question: "Where is the highest level of direct responsibility for climate change within your company?" Firms had four choices to identify the position of the individual or name of the committee with this responsibility, namely, (i) board: the board or other committee appointed by the board; (ii) senior manager/officer; (iii) other manager/officer; and (iv) no individual or committee.

pay_incentives was constructed based on the CDP question: "Do you provide incentives for the management of climate change issues, including the attainment of targets?" Firms responded to this question by selecting "Yes" or "No".

intentives_type. If firms responded that employees could benefit from incentive programmes related to climate change, they were asked to provide information about the types of incentive they were paying. The former question contains a set of predefined categories, namely, monetary, recognition (non-monetary) or other non-monetary incentives. The CDP defines monetary incentives as a bonus or some form of financial remuneration; recognition (non-monetary): employee award (e.g. employee of the year) or career-progression scheme, but not tied directly to any form of financial remuneration; other non-monetary reward, including increased holiday allowances, special assignments, parking allocations, and so on. These definitions are also supported by (I1988)and (Gomez-Mejia, Luis R, Balkin David B1995).

incentives_entitiled. In addition, firms had to identify who is entitled to benefit from the selected incentives. The CDP provided 17 predefined categories of employee for this question. In this research we grouped them into four main categories, as follows:

i. Board: board chairman; board/executive board; director on board; corporate executive team; CEO; COO; executive officer; management group.

ii. Sustainability team: energy managers; environmental sustainability managers; risk managers; other.

iii. Other managers: business unit managers; facilities managers; process operation managers; public affairs managers.

iv. All employees: all employees.

publishing_cc_reports. Firms were asked about communication of their position on climate change and carbon emissions outside their CDP response. They had to answer the following question: "Have you published information about your company's response to climate change and GHG emissions performance for this reporting year in places other than in your CDP response? If so, please attach 
the publication(s)". In this study, we brought the firms' responses to the same level of detail and created three main categories, namely: (i) annual reports refer to the mandatory annual financial reporting, published to meet regulatory obligations;(ii) voluntary communication if firms have published optional sustainability/CSR reports; (iii) other regulatory filings are those required through regional or national legislation, examples being the SEC filing in the US, reports made under the AB32 and EPA federal reporting rule, ETS regulation submissions, or Victorian Energy Efficiency Target (VEET) filings in Australia.

It was chosen to use binary representation of the variables in all the experiments, facilitating easier manipulation and aggregation. The value of this variable ranges from 0 to 7 , where 7 shows that the firm publishes its climate change information in all of the three categories, and 0 shows that the firm is not publishing in any of them.

Board characteristics data. We employed two sets of board variables in this study. The first set of board variables measured board monitoring and incentives, as discussed under agency theory, including director independence, CEO-chair duality, CEO-director ownership, insider-director ownership and outsider-director ownership. The measurement of these variables was consistent with prior research (de Villiers et al. 2011). All the variables were calculated based on the RiskMetrics dataset.

Director independence is measured as a percentage of the number of independent directors on the board. CEO-chair duality is coded as 1 if the CEO also serves as the board chairman, and otherwise as 0.CEO-director ownership captures the percentage of the total number of shares held by a board member who is also the firm's CEO. Insider-director ownership is measured as the cumulative percentage of the total number of shares held by the remaining executive (i.e. non-CEOs) board members. Similarly, outsider-director ownership is the cumulative percentage of the total outstanding shares held by outsider (i.e. non-executive) board members.

The second set of board variables measures the provision of resources by directors, as discussed under resource-dependence theory, and includes board size, board tenure and board social network. Board tenure is calculated based on the available data from the RiskMetrics database and other metrics are calculated using the BoardEx dataset.

Board size is the number of directors on the board. Board tenure is measured as the average number of years the firm's directors have served on the board(de Villiers et al. 2011). Boardroom social network is defined and calculated as follows. 
We obtained information on firms' board of directors from the BoardEx dataset, which keeps information about individuals, mainly from the USA and Europe, who work in publicly quoted firms and major private entities at board of director and executive management levels. The information includes in-depth profiles such as academic qualifications, current and past job positions, membership of professional and other bodies, and is collected and revised semi-automatically by analysts in charge of collecting, processing and updating information about such individuals. Once the information is validated, BoardEx provides business networking services to firms and individuals wishing to obtain information about certain individuals and their contacts (positive interpersonal ties) and the relationship of their contacts with other individuals (social network). Using BoardEx data from 2009 to 2011, we built an undirected and unweighted social network at board level, defined as follows:

"Current Employment (CE) Network of S\&P firms". Two S\&P firms are linked through a director if two firms share the same director. This is the traditional interlocking directorship network. Moreover, if directors from two firms sit on the board of a third company, this will form the CE of S\&P firms as well. Multiple links between two S\&P firms through different S\&P directors are assumed to be the same. Table 1 reports the summary statistics on the CE network for S\&P1500 firms. On average, we have 1,411 firms and 1,380 directors per year. After building the social network at firm level through the social ties of board members, we are able to capture the firm's position in relation to others on the entire network by calculating degree centrality, betweenness centrality, closeness centrality and eigenvector (Shahgholian et al. 2015).

\begin{tabular}{|llll|}
\hline Year & 2009 & 2010 & 2011 \\
\hline \#Firms & 1,408 & 1,411 & 1,414 \\
\hline \#Links & 27,253 & 27,628 & 28,143 \\
\hline \#Directors & 1,378 & 1,383 & 1,380 \\
\hline Size of largest component & 1,400 & 1,405 & 1,407 \\
\hline
\end{tabular}

Table 1. Summary statistics of CE network characteristics

\section{Results}

Table 2 displays the results of the first step in the clustering analysis framework for each year. The recorded Silhouette Coefficient evaluates the clustering model in each year. Based on this score we can see that clusters in each year have fair quality. We can distinguish two clusters in each year. The first cluster ( $\mathrm{C} 1$ ) described the firms that are not particularly well connected. Compared to the second cluster (C2), they have fewer direct links to other firms (degree), their neighbours are also 
not very well connected to the rest of the network directly (eigenvector), they have less direct access to the rest of the network (closeness) and they participate less in transmitting information between other firms in the network (betweenness). Therefore, the first cluster (C1) is defined as a "socially independent" ( $\mathrm{SI}$ ) cluster and the second as a "socially connected" (SC) cluster. The clusters in each year follow the same pattern.

The size of socially connected clusters is smaller than socially independent clusters in each year, but the size gradually increases over the year from 39.1 per cent in 2009 to 42.1 per cent in 2011 . The increased size can be interpreted as the social network evolution of firms over time, where more firms are connected based on their connection in this year, and therefore there will be a greater number of socially connected firms. In addition, the social network metrics are sorted by overall importance. Therefore, someone can conclude that degree and eigenvector are the most important metrics in each year to form the clusters. Closeness and betweenness have the same order in 2009 and 2011, while in 2010 betweenness is more important than closeness to form the clusters.

\begin{tabular}{|c|c|c|c|c|c|c|c|c|c|}
\hline & \multicolumn{3}{|c|}{2009} & \multicolumn{3}{|c|}{2010} & \multicolumn{3}{|c|}{2011} \\
\hline Silhouette & \multicolumn{3}{|c|}{0.6} & \multicolumn{3}{|c|}{0.7} & \multicolumn{3}{|c|}{0.7} \\
\hline Cluster number & \multirow[t]{2}{*}{ Metrics } & $\mathrm{C} 1$ & $\mathrm{C} 2$ & \multirow[t]{2}{*}{ Metrics } & $\mathrm{C} 1$ & $\mathrm{C} 2$ & \multirow[t]{2}{*}{ Metrics } & $\mathrm{C} 1$ & $\mathrm{C} 2$ \\
\hline \multirow[t]{5}{*}{ Cluster size (\%) } & & 60.9 & 39.1 & & 60.2 & 39.8 & & 57.9 & 42.1 \\
\hline & $\bar{D}$ & 54.00 & 123.00 & D & 50.46 & 119.98 & $\bar{D}$ & 48.75 & 116.57 \\
\hline & $E$ & 3.45 & 9.74 & $E$ & 3.23 & 9.37 & $E$ & 3.08 & 9.04 \\
\hline & C & 42.10 & 46.85 & B & 0.13 & 0.44 & C & 41.86 & 46.88 \\
\hline & B & 0.15 & 0.44 & C & 41.95 & 46.96 & B & 0.12 & 0.41 \\
\hline
\end{tabular}

Table 2. Social network clusters and their statistics per year; Note: $D=$ degree, $E=$ normalised eigenvector, $C=$ normalised closeness; $B=$ normalised betweenness

As discussed in the literature review section, we considered two groups of board characteristics: board resource-provision characteristics and board-monitoring and incentive characteristics. In this step, the clustering model was applied to each set of attributes separately in order to find the clusters. First, the K-Means algorithm was applied to board resource-provision variables, which are board tenure, board size and social network clusters obtained from the previous step. Table 3 presents the clusters in each year. The recorded Silhouette in each year is 0.7 , which indicates that the clustering quality is fair in each year. The order of variables in all years is the same. Apparently the social network variable is the most important variable to distinguish two clusters. It is now possible to appreciate how firms that are members of the socially connected (SC) cluster also possess better indicators in terms of board resource provision. Considering the results in 2009, it can 
be concluded that socially connected (SC) firms have a greater average of board size. However, lower board tenure indicates that the average number of years the firms' directors have served on the board is smaller. This means that firms have hired directors more recently. Therefore, it is more likely that directors have more knowledge and expertise in relation to environmental performance through their previous directorships in other firms. The same results appear between firms in the years 2010 and 2011. Therefore, the first cluster (C1) is defined as a "board with poor resource provision role" ( $\left(\mathrm{RP}_{\text {poor }}\right)$ cluster and the second as a "board with rich resource provision role" ( $\left.\mathrm{RP}_{\text {rich }}\right)$ cluster. The clusters in each year follow the same pattern.

\begin{tabular}{|c|c|c|c|c|c|c|}
\hline & \multicolumn{2}{|c|}{2009} & \multicolumn{2}{|c|}{2010} & \multicolumn{2}{|c|}{2011} \\
\hline Silhouette & \multicolumn{2}{|c|}{0.7} & \multicolumn{2}{|c|}{0.7} & \multicolumn{2}{|c|}{0.7} \\
\hline Cluster number & $\mathrm{C} 1$ & $\mathrm{C} 2$ & C1 & $\mathrm{C} 2$ & C1 & $\mathrm{C2}$ \\
\hline Cluster size (\%) & 60 & 40 & 60.2 & 39.8 & 57.9 & 42.1 \\
\hline Social network connectedness & $\mathrm{SI}$ & SC & $\mathrm{SI}$ & SC & $\mathrm{SI}$ & SC \\
\hline Board size & 10.71 & 12.54 & 10.71 & 12.54 & 10.65 & 12.27 \\
\hline Board tenure & 10.38 & 9.80 & 10.38 & 9.80 & 10.43 & 10.11 \\
\hline
\end{tabular}

Table 3. Board resource-provision clusters and their statistics per year; Note: $\mathrm{SI}=$ socially independent, $\mathrm{SC}=$ socially connected

At this stage, we turned our attention to clustering the board-monitoring and stock-incentive variables. The K-Means model was applied to the data in each year. Table 4 presents the results in each year; two clusters in each year are identified namely board with high monitoring role and board with low monitoring role. The recorded Silhouette for each year indicates that the quality of clustering is fair. Considering the results in 2009 , it can be concluded that in cluster $\mathrm{C} 1$ the number of independent directors is higher than in cluster C2. Stock ownership is as expected; insiderdirectors own more stock, which encourages them to protect shareholder interests more. In addition, outsider-directors own little stock, which means they are not particularly dependent on firm stock and they can influence the board's decisions and monitor firm management independently. On the other hand, the number of CEOs owning a high percentage of stock, as well as CEO-chairman duality, is higher. One possible interpretation of this is that CEO interests could be in line with shareholder interests because of their share ownerships. In this case, we should not be too concerned about the contrasts between CEO and shareholders' interests. In this situation, higher CEO-chairman duality could help the CEO and board to be more focused on the decision-making process related to shareholder's interests. 


\begin{tabular}{|c|c|c|c|c|c|c|c|c|c|}
\hline & \multicolumn{3}{|c|}{2009} & \multicolumn{3}{|c|}{2010} & \multicolumn{3}{|c|}{2011} \\
\hline Silhouette & \multicolumn{3}{|c|}{0.6} & \multicolumn{3}{|c|}{0.7} & \multicolumn{3}{|c|}{0.7} \\
\hline Cluster number & \multirow[t]{2}{*}{ Metrics (\%) } & $\mathrm{C} 1$ & $\mathrm{C} 2$ & \multirow[t]{2}{*}{ Metrics(\%) } & $\mathrm{C} 1$ & $\mathrm{C} 2$ & \multirow[t]{2}{*}{ Metrics(\%) } & $\mathrm{C} 1$ & $\mathrm{C} 2$ \\
\hline \multirow[t]{6}{*}{ Cluster size (\%) } & & 54.7 & 45.3 & & 78.5 & 21.5 & & 48.4 & 51.6 \\
\hline & $\mathrm{CEO}_{\text {Own }}$ & 76.40 & 6.25 & Insider ${ }_{\text {Own }}$ & 80.85 & 22.46 & $\mathrm{CEO}_{\text {Own }}$ & 77.65 & 7.14 \\
\hline & Outsider $_{\text {Own }}$ & 19.09 & 43.85 & Outsider $_{\text {Own }}$ & 19.15 & 77.54 & Outsider $_{\text {Own }}$ & 18.36 & 44.58 \\
\hline & Insider ${ }_{\text {Own }}$ & 80.91 & 56.15 & $\mathrm{CEO}_{\text {Own }}$ & 56.06 & 9.31 & Insider ${ }_{\text {Own }}$ & 81.64 & 55.43 \\
\hline & IndDir & 85.28 & 80.09 & IndDir & 83.83 & 81.67 & IndDir & 86.57 & 81.92 \\
\hline & CEO duality & 0.11 & 0.08 & CEO duality & 0.08 & 0.07 & CEO duality & 0.08 & 0.02 \\
\hline
\end{tabular}

Table 4. Board-monitoring clusters and their statistics per year;

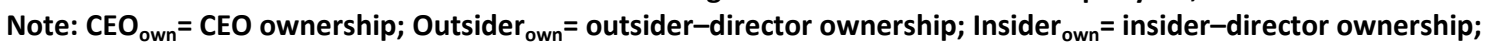
IndDir= independent director; CEO duality= CEO-chairman duality

This stage profiles the firms' environmental governance with respect to the board-monitoring and board resource-provision profiles. Table 5 shows the results. The environmental governance variables are paying incentives (PI), publishing climate change information (CCP) and the climate change responsible team (CCR). The general pattern each year is that when the board is in a better position in terms of monitoring and resource provision, there is a high possibility (at least $77.9 \%$ ) that the board will be directly responsible for climate change issues in the firm. They publish the climate change information in the firms' annual reports and voluntary reports. In addition, they pay incentives for environmental activities to entitled people.

\begin{tabular}{|c|c|c|c|c|c|c|c|c|c|}
\hline & \multicolumn{3}{|c|}{2010} & \multicolumn{3}{|c|}{2011} & \multicolumn{3}{|c|}{2012} \\
\hline Silhouette & \multicolumn{3}{|c|}{0.3} & \multicolumn{3}{|c|}{0.2} & \multicolumn{3}{|c|}{0.3} \\
\hline Cluster number & \multirow[t]{2}{*}{ Metrics } & C1 & $\mathrm{C} 2$ & \multirow[t]{2}{*}{ Metrics } & $\mathrm{C} 1$ & $\mathrm{C} 2$ & \multirow[t]{2}{*}{ Metrics } & $\mathrm{C} 1$ & $\mathrm{C} 2$ \\
\hline \multirow[t]{6}{*}{ Cluster size (\%) } & & 54.2 & 45.8 & & 53.5 & 46.5 & & 55.5 & 44.5 \\
\hline & $\mathrm{PI}$ & $\begin{array}{c}\text { Yes } \\
(77.0 \%)\end{array}$ & $\begin{array}{c}\text { No } \\
(77.7 \%)\end{array}$ & CCR & $\begin{array}{c}\text { SM } \\
(59.9 \%)\end{array}$ & $\begin{array}{c}\text { Board } \\
\text { (89.1\%) }\end{array}$ & BM & $\begin{array}{c}\text { Low } \\
(78.7 \%)\end{array}$ & $\begin{array}{l}\text { High } \\
(82.3 \%)\end{array}$ \\
\hline & CCP & $\begin{array}{c}7 \\
(75.4 \%)\end{array}$ & $\begin{array}{c}3 \\
(40.8 \%)\end{array}$ & $\mathrm{PI}$ & $\begin{array}{c}\text { No } \\
(58.4 \%)\end{array}$ & $\begin{array}{c}\text { Yes } \\
(97.5 \%)\end{array}$ & BRP & $\begin{array}{c}\text { Poor } \\
(84.4 \%)\end{array}$ & $\begin{array}{c}\text { Rich } \\
(75.2 \%)\end{array}$ \\
\hline & CCR & $\begin{array}{l}\text { Board } \\
(91 \%)\end{array}$ & $\begin{array}{c}\text { Board } \\
(46.6 \%)\end{array}$ & CCP & $\begin{array}{c}2 \\
(28.5 \%) \\
\end{array}$ & $\begin{array}{c}6 \\
(37.0 \%) \\
\end{array}$ & $\mathrm{PI}$ & $\begin{array}{c}\text { Yes } \\
(60.3 \%)\end{array}$ & $\begin{array}{c}\text { Yes } \\
(90.3 \%)\end{array}$ \\
\hline & BM & $\begin{array}{c}\text { High } \\
(74.6 \%)\end{array}$ & $\begin{array}{c}\text { Low } \\
(68.9 \%)\end{array}$ & BRP & $\begin{array}{c}\text { Poor } \\
(70.1 \%)\end{array}$ & $\begin{array}{c}\text { Rich } \\
(51.3 \%)\end{array}$ & $\mathrm{CCR}$ & $\begin{array}{c}\text { SM } \\
(48.2 \%) \\
\end{array}$ & $\begin{array}{c}\text { Board } \\
(77.9 \%)\end{array}$ \\
\hline & BRP & $\begin{array}{l}\text { Rich } \\
(59 \%)\end{array}$ & $\begin{array}{l}\text { Poor } \\
(82 \%)\end{array}$ & BM & $\begin{array}{c}\text { High } \\
(76.6 \%)\end{array}$ & $\begin{array}{c}\text { High } \\
(80.7 \%) \\
\end{array}$ & CCP & $\begin{array}{c}2 \\
(29.1 \%) \\
\end{array}$ & $\begin{array}{c}6 \\
(37.2 \%) \\
\end{array}$ \\
\hline
\end{tabular}

Table 5. Board and environmental governance clustering and their results per year

Note: $\mathrm{PI}=$ pay incentives, $\mathrm{CCP}=$ climate change publishing, $\mathrm{CCR}=$ climate change responsibility, board monitoring= $\mathrm{BM}$; $\mathrm{BRP}=$ board resource provision

To this point, we have discovered that when the board has higher monitoring of management and is also resource-rich, it is directly responsible for climate change issues in the firm and is definitely paying incentives and publishing climate change information. When firms were responding to the CDP questionnaire, if the firm confirmed the payment of incentives then they had to answer two more questions to specify who was entitled to benefit from these incentives and the type of 
incentives involved. Figure 2 presents the type of incentives for each group, or individuals, entitled to incentives. In Figure 2, panel A, the type of incentives for the board are plotted. It is clear that monetary incentives are higher than other types of incentive. Boards received the highest percentage of monetary incentives in 2011. Paying recognition incentives to the boards increased slightly from 2011 to 2012. However, the percentage of non-monetary incentives remained relatively stable. Figure 2, Panel B indicates the type of incentives for the sustainability team. This group also received a very high percentage of monetary incentives. While their non-monetary incentives declined from 2010 to 2012, there was a significant increase in the percentage of recognition and monetary incentives from 2010 to 2012. As shown in Figure 2, Panel C, firms are paying a higher percentage of monetary incentives to other managers in the firm compared to nonmonetary and recognition incentives. In contrast to the boards and sustainability team, the recognition incentives for this group declines over time.

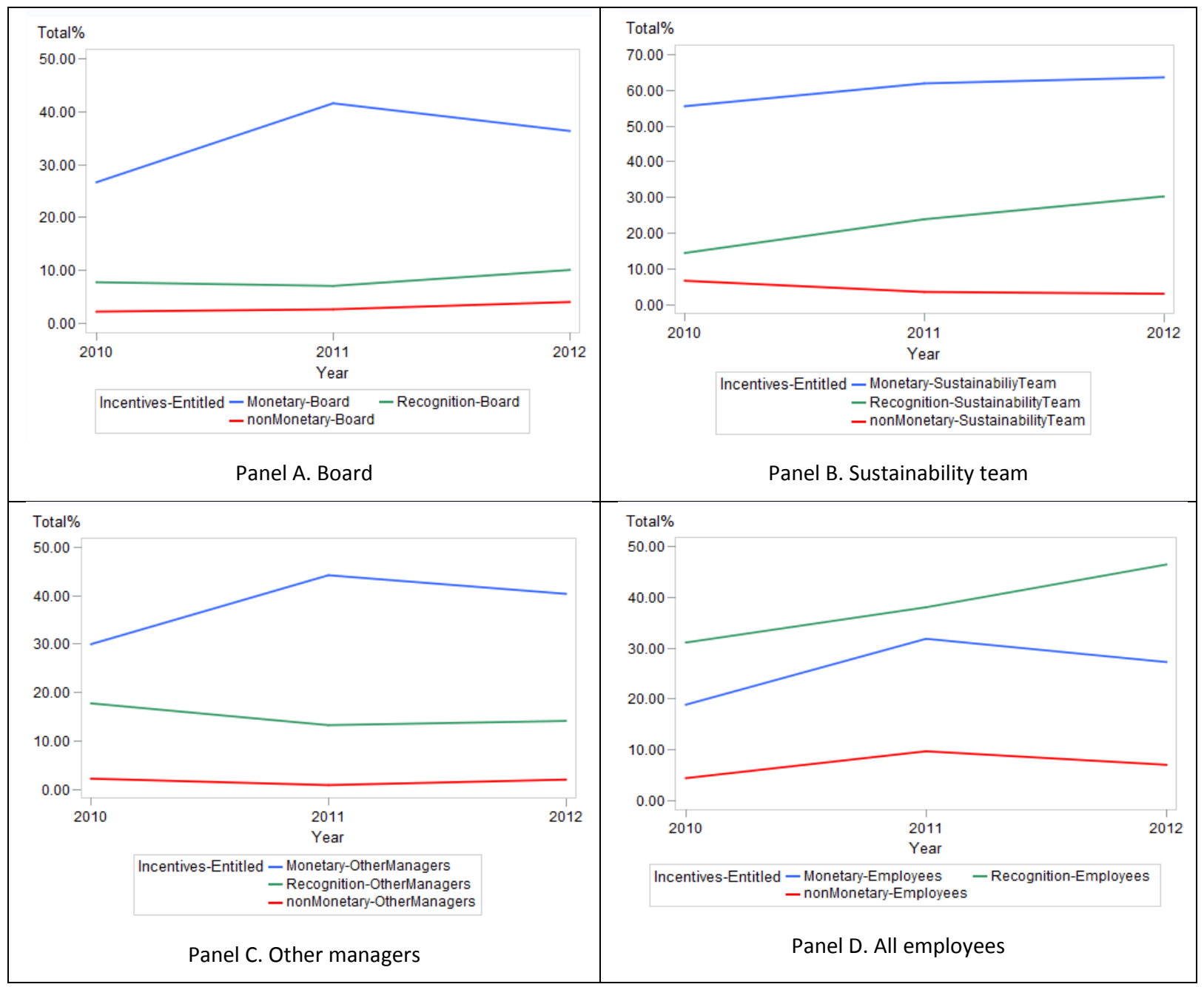

Figure 2. Percentage of three types of incentive per the entitled group for incentives

Figure 2, Panel D shows the percentage of the type of incentives assigned to all employees in the firm. Unlike the other three groups, employees are entitled to recognition incentives that are much 
higher than other types of incentive. The reason could be that when the board has direct responsibility for climate change issues in the firm, it is more likely to promote the environmental agenda through giving incentives to all employees.

\section{Discussion and Conclusion}

This work has explored the extent to which a board of directors with both monitoring and resourceprovision roles affects a firm's environmental governance. We identified the potential advantage of the appointment of experienced directors to the board and their social networking with directors from other firms to create value in relation to the firm's environmental governance. In addition, a board with an effective monitoring role can help management to pursue environmental governance. We investigated the relationship between environmental governance and several board characteristics, which are categorised as the monitoring role of directors linked to agency theory and the resource-provision role of directors linked to resource-dependence theory. Consistent with resource-dependence theory, we show that board social network connections are the most important factor in providing information. Boards with better social network connectedness, larger board size and lower board tenure are classified as resource-rich boards. Consistent with agency theory, the board of directors monitors the implementation of decisions made by the board. Effective boards increase their monitoring of management when there are a higher number of independent directors on the board, higher CEO-chairman duality, higher share ownership for insiders and CEOs and lower share ownership for outsider-directors.

In addition, a resource-rich board with an effective monitoring role tends to have a board, or a committee appointed by the board, to be responsible for environmental initiatives, paying incentives for the management of climate change issues and publishing information in annual reports, voluntary communications or other regulatory filings.

Research on the environmental profile of firms limits their environmental variable to just one variable, such as $\mathrm{CO}_{2}$ emissions (Misani and Pogutz 2015) or KLD strengths (de Villiers et al. 2011), because they need to have one dependent variable in the statistical model, such as regression analysis. This study employs data-mining techniques, which provide us with the opportunities to find patterns between a set of board characteristics and a set of environmental governance using a clustering technique. In addition, we use the integration of agency theory and resource-dependence theory to define the role of the board of directors in terms of monitoring and resource-dependence theory. Our analysis presents the finding that two complimentary roles are necessary in relation to environmental governance. In addition, the social network between boards of directors is defined as 
one of the important factors that could facilitate access to resources and information based on the position of firms in the network. Various social network centrality metrics are employed to describe the position of the board of directors. Therefore, our study is the first to justify the social network based on resource-dependence theory and to consider its impact on environmental governance.

The practical implication of our study is for firms interested in developing their environmental profile. Taking into consideration the importance of the board of directors in relation to the board resource-provision and monitoring role, firms should be more careful when appointing directors. The board needs directors who are knowledgeable in the environmental domain and can provide the relevant resources through their expertise and social networks with other sources. When the board has a reasonable level of understanding of environmental profile and an effective monitoring capability, it is able to pursue managers for business opportunities related to environmental products and services. In other words, firms should set up board structures and characteristics for an environmental profile. They should consider not only static board characteristics such as board independence, but also rational characteristics such as social network.

We acknowledge that our study has several limitations. First, this study analyses a period of three years; a longitudinal study approach covering an extended period of time would reveal more patterns. The main reason for this is that an environmental agenda usually requires long-term plans and investment. Second, the study focuses on board characteristics. However, we cannot ignore the role of firm characteristics such as firm age, firm size, industry sensitivity and the firm's financial situation in terms of environmental investment. Third, our sample comprises mainly the S\&P1500 firms in the US, which are large firms (large-cap US equities). Although it is obvious that large firms are more visible and, as a result, more active in the environmental agenda and engaging in various voluntary environmental programmes, for small- and medium-sized firms the link between board social networking and other board characteristics with environmental profile could be different.

Beyond our study's limitations, there are a number of promising areas of future research. First, based on the resource-dependence theory, this study shows that knowledge and information gathered by members of the board leads the board of directors to pursue better environmental practices. Future research could explore the importance of board environmental experience such as membership of an environmental committee or their previous role involving environmental-related programmes. Second, following other studies that integrate agency theory and resourcedependence theory (Hillman and Dalziel 2003)(de Villiers et al. 2011)(Zona et al. 2015), our study also provides support for this integration. By taking into consideration that the board decisionmaking process is complex, the use of any of these theories alone may not be sufficient. Therefore, 
the integration of agency and resource-dependence theories could provide more insight into other board-related outcomes. Third, this research employs the common social network centrality metrics. For future research, we recommend exploring the evolution of the board social network (Shahgholian et al. 2012) and how social network evolution could affect firms' environmental profiles.

\section{References}

Armstrong, C.S., Core, J.E. and Guay, W.R. (2014). Do independent directors cause improvements in firm transparency? Journal of Financial Economics, 113(3), pp.383-403.

Bahaghat, S. and Black, B. (1999). The uncertian relationship between board composition and firm performance. Business Lawyer, 54, pp.921-963.

Berrone, P. and Gomez-Mejia, L.R. (2009). ENVIRONMENTAL PERFORMANCE AND EXECUTIVE COMPENSATION: AN INTEGRATED AGENCY-INSTITUTIONAL PERSPECTIVE. Academy of Management Journal, 52(1), pp.103-126.

BoardEx. (2016). Management Diagnostics Limited. [online]. Available from:

http://www.boardex.com/ [Accessed March 1, 2016].

Busch, T. and Hoffmann, V.H. (2011). How Hot Is Your Bottom Line? Linking Carbon and Financial Performance. Business \& Society, 50(2), pp.233-265.

Carbon Disclosure Project. (2013). Carbon Disclosure Project (CDP). [online]. Available from: http://www.cdproject.net.

Carbon Disclosure Project. (2014). Catalysing business and government action. [online]. Available from: https://www.cdp.net/en-US/Pages/About-Us.aspx.

Cong, Y. and Freedman, M. (2011). Corporate governance and environmental performance and disclosures. Advances in Accounting, incorporating Advances in International Accounting, 27(2), pp.223-232.

Conyon, M. (2006). Executive Compensation, Taxes, and Incentives. Academy of Management Perspecitives, pp.179-201.

Cordeiro, J.J. and Sarkis, J. (2008). Does explicit contracting effectively link CEO compensation to environmental performance? Business Strategy and the Environment, 17(5), pp.304-317.

Cuadrado-Ballesteros, B., Rodríguez-Ariza, L. and García-Sánchez, I.-M. (2015). The role of independent directors at family firms in relation to corporate social responsibility disclosures. International Business Review, 24, pp.890-901.

Dalton, D.R. et al. (1999). Number of directors and financial performance: A meta-analysis. Academy of Management Journal, 42(6), pp.674-686.

Diaz, D., Theodoulidis, B. and Shahgholian, A. (2013). Social Networking Influence on Environmental and Corporate Performance. 2013 IEEE International Conference on Business Informatics, pp.63-68.

Drees, J.M. and Heugens, P.P.M. a R. (2013). Synthesizing and Extending Resource Dependence Theory: A Meta-Analysis. Journal of Management, 39(6), pp.1666-1698.

Duchin, R., Matsusaka, J.G. and Ozbas, O. (2010). When are outside directors effective? Journal of Financial Economics, 96(2), pp.195-214. 
Fogel, K., Ma, L. and Morck, R. (2014). Powerful Independent Directors.

Fracassi, C. (2015). Corporate Finance Policies and Social Networks. SSRN eLibrary. [online]. Available from: http://dx.doi.org/10.2139/ssrn.1121503.

Fracassi, C. and Tate, G. (2012). External Networking and Internal Firm Governance. Journal of Finance, 67(1), pp.153-194.

Fujii, H. et al. (2013). Corporate Environmental and Economic Performance of Japanese Manufacturing Firms: Empirical Study for Sustainable Development. Business Strategy and the Environment, 22(3), pp.187-201.

Golden, B.R. and Zajac, E.J. (2001). When will boards influence strategy? Inclination $\times$ power = strategic change. Strategic Management Journal, 22(12), pp.1087-1110.

Gomez-Mejia, Luis R, Balkin David B, C.R.L. (1995). Managing Human Resources. New Jersey: Prentice Hall.

Goyal, V.K. and Park, C.W. (2002). Board leadership structure and CEO turnover. Journal of Corporate Finance, 8(1), pp.49-66.

Granovetter, M. (1985). Economic Action and Social Structure: The Problem of Embeddedness. American Journal of Sociology, 91(3), pp.481-510.

Hatakeda, T. et al. (2012). Factors Influencing Corporate Environmental Protection Activities for Greenhouse Gas Emission Reductions: The Relationship Between Environmental and Financial Performance. Environmental and Resource Economics, 53(4), pp.455-481.

Hillman, a. J., Withers, M.C. and Collins, B.J. (2009). Resource Dependence Theory: A Review. Journal of Management, 35(6), pp.1404-1427.

Hillman, A. and Dalziel, T. (2003). Boards of directors and firm performance: Integrating agency and resource dependence perspectives. Academy of Management Review, 28(3), pp.383-396.

Horton, J., Millo, Y. and Serafeim, G. (2012). Resources or power? Implications of social networks on compensation and firm performance. Journal of Business Finance \& Accounting, 39(3-4), pp.399426.

Hwang, B.-H. and Kim, S. (2009). It pays to have friends. Journal of Financial Economics, 93(1), pp.138-158.

I, H.R. (1988). Job evaluation, classification and pay. In In The Job Analysis Handbook for Business, Industry and Government, Volume 1.

Ienciu, I.-A., Popa, I.E. and lenciu, N.M. (2012). Environmental Reporting and Good Practice of Corporate Governance: Petroleum Industry Case Study. Procedia Economics and Finance, 3(12), pp.961-967.

Khanna, M. and Anton, W. (2002). Corporate environmental management: regulatory and marketbased incentives. Land Economics, 78(4), pp.539-558. [online]. Available from: http://171.66.125.237/content/78/4/539.short.

Kim, E. and Lyon, T. (2011). When Does Institutional Investor Activism Increase Shareholder Value?: The Carbon Disclosure Project. The B.E. Journal of Economic Analysis \& Policy, 11(1).

Lankoski, L. (2008). Corporate Responsibility Activities and Economic Performance : a Theory of Why and How They Are Connected. Business Strategy and the Environment, 17, pp.536-547.

Larcker, D., So, E. and Wang, C. (2013). Boardroom centrality and firm performance. Journal of Accounting and Economics, 55(2-3), pp.225-250.

Lee, S.-Y., Park, Y.-S. and Klassen, R.D. (2013). Market Responses to Firms' Voluntary Climate Change Information Disclosure and Carbon Communication. Corporate Social Responsibility and 
Environmental Management, (February 2013), p.n/a-n/a.

Lemos, M.C. and Agrawal, A. (2006). Environmental Governance. Annual Review of Environment and Resources, 31(1), pp.297-325.

Liao, L., Luo, L. and Tang, Q. (2014). Gender diversity, board independence, environmental committee and greenhouse gas disclosure. British Accounting Review, pp.1-16.

Matisoff, D.C., Noonan, D.S. and O'Brien, J.J. (2013). Convergence in Environmental Reporting: Assessing the Carbon Disclosure Project. Business Strategy and the Environment, 22(5), pp.285-305. [online]. Available from: http://doi.wiley.com/10.1002/bse.1741 [Accessed September 22, 2013].

Misani, N. and Pogutz, S. (2015). Unraveling the effects of environmental outcomes and processes on financial performance: A non-linear approach. Ecological Economics, 109, pp.150-160.

Mizruchi, M.S. (1996). What Do Interlocks Do? An Analysis, Critique, and Assessment of Research on Interlocking Directorates. Annual Review of Sociology, 22(1996), pp.271-298.

Musteen, M., Barker, V.L. and Baeten, V.L. (2006). CEO attributes associated with attitude toward change: The direct and moderating effects of CEO tenure. Journal of Business Research, 59(5), pp.604-612.

Ortiz-de-Mandojana, N. et al. (2012). The effect of director interlocks on firms' adoption of proactive environmental strategies. Corporate Governance, 20(2), pp.164-178.

Ortiz-de-Mandojana, N. and Aragon-Correa, J.A. (2013). Boards and Sustainability: The Contingent Influence of Director Interlocks on Corporate Environmental Performance. Business Strategy and the Environment.

Pfeffer, J. and Salancik, G. (1978). The external control of organizations: A resource-dependence perspective. New York: Harper \& Row.

Pintea, M.-O. et al. (2014). Is there a Connection among Environmental and Financial Performance of a Company in Developing Countries? Evidence from Romania. Procedia Economics and Finance, 15(14), pp.822-829.

Post, C., Rahman, N. and McQuillen, C. (2014). From Board Composition to Corporate Environmental Performance Through Sustainability-Themed Alliances. Journal of Business Ethics.

Post, C., Rahman, N. and Rubow, E. (2011). Green Governance: Boards of Directors' Composition and Environmental Corporate Social Responsibility.

Poulain-Rehm, T. and Lepers, X. (2013). Does Employee Ownership Benefit Value Creation? The Case of France (2001-2005). Journal of Business Ethics, 112(2), pp.325-340.

Prado-Lorenzo, J.M. and Garcia-Sanchez, I.M. (2010). The Role of the Board of Directors in Disseminating Relevant Information on Greenhouse Gases. Journal of Business Ethics, 97(3), pp.391424.

Pugliese, A., Minichilli, A. and Zattoni, A. (2014). Integrating agency and resource dependence theory: Firm profitability, industry regulation, and board task performance. Journal of Business Research, 67(6), pp.1189-1200.

Qi, Q. (2011). How Does the Director's Social Network Matter? Evidence from Structure Estimation. Working paper, Fudan University.

Rodrigue, M., Magnan, M. and Cho, C.H. (2013). Is Environmental Governance Substantive or Symbolic? An Empirical Investigation. Journal of Business Ethics, 114(1), pp.107-129.

Romano, G. and Guerrini, A. (2012). Corporate governance and accounting enforcement actions in Italy. Managerial Auditing Journal, 27(7), pp.622-638.

Russo, M. V and Harrison, N.S. (2005). Organizational design and environmental performance. Clues 
from the electronics industry. Academy of Management Journal, 48(4), pp.582-593.

Scott, M. (2014). Re-theorizing social network analysis and environmental governance: Insights from human geography. Progress in Human Geography, 39(4), pp.449-463.

Shahgholian, a, Theodoulidis, B. and Bansal, U. (2012). Social Network Evolution: A Case Study of Uk Directors. 2012 Third International Conference on Services in Emerging Markets (Icsem), pp.107-114.

Shahgholian, A., Muscalu, R. and Theodoulidis, B. (2014). The impact of social networks of SP1500 companies vision on environmental governance. In AHFE International 5th International Conference on Applied Human Factors and Ergonomics.

Shahgholian, A., Theodoulidis, B. and Diaz, D. (2014). Environmental Performance: A case study of the impact of Social Networks and Environmental Governance. In 49th Annual Meeting Cladea 2014.

Shahgholian, A., Theodoulidis, B. and Diaz, D. (2015). Social Network Metrics: The BoardEx case study. Working paper, the University of Manchester.

Shivdasani, A. (1993). Board composition, ownership structure and hostile takeovers: some UK evidence. Journal of Accounting and Economics, 16, pp.167-198.

Tao, P. and Zhang, Q. (2014). Study on relationship between environmental performance and corporate financial performance-Based on listed companies in heavy polluting industries. 2014 International Conference on Management Science \& Engineering (21th), pp.1127-1134.

Tsai, W. and Ghoshal, S. (1998). Social Capital and Value Creation: The Role of Intrafirm Networks. Academy of management Journal, 41(4), pp.464-476.

Uhlaner, L.M. et al. (2012). Beyond Size: Predicting Engagement in Environmental Management Practices of Dutch SMEs. Journal of Business Ethics, 109(4), pp.411-429.

de Villiers, C., Naiker, V. and van Staden, C.J. (2011). The Effect of Board Characteristics on Firm Environmental Performance. Journal of Management, 37(6), pp.1636-1663.

Walls, J., Berrone, P. and Phan, P. (2012). Corporate Governance and Environmental Performance: Is There Really a Link? Strategic Management Journal, 913(December 2011), pp.885-913.

Walls, J. and Hoffman, A. (2013). Exceptional boards: Environmental experience and positive deviance from institutional norms. Journal of Organizational Behavior, 271(March 2012), pp.253271.

Walls, J.L., Berrone, P. and Phan, P.H. (2012). CORPORATE GOVERNANCE AND ENVIRONMENTAL PERFORMANCE : IS THERE REALLY A LINK ? Strategic Management Journal, 913(December 2011), pp.885-913.

Wang, W. (2014). Independent Directors and Corporate Performance in China : A Meta-empirical Study. International Journal of Business and Management, II(3).

Westphal, J.D. (1999). Collaboration in the Boardroom : Behavioral and Performance Consequences of Ceo- Board Social Ties. Academy of Management Journal, 42(1), pp.7-24.

Zona, F., Gomez-Mejia, L.R. and Withers, M.C. (2015). Board interlocks and firm performance: Toward a combined agency-resource dependence perspective. Journal of Management, in print, pp.1-30.

Zou, H.L. et al. (2014). Are Top Executives Rewarded for Environmental Performance? The Role of the Board of Directors in the Context of China. Human and Ecological Risk Assessment: An International Journal, (December 2014), pp.1-24. 